\title{
LEARNING TO COLLABORATION: CAN INTEGRATED LEARNING IMPROVE STUDENTS PERCEPTIONS AND OUTCOMES?
}

\author{
Estefanía Osorio-Acosta ${ }^{1}$, Eva M $^{\mathrm{a}}$ Mestre-Mestre $^{2}$, Alberto Palomares ${ }^{3}$ \\ ${ }^{1}$ Dept. Economía y Ciencias Sociales Universitat Politècnica Valencia (SPAIN) \\ ${ }^{2}$ Dept. Lingüística Aplicada. Universitat Politècnica Valencia (SPAIN) \\ ${ }^{3}$ Dept. Sistemas Informáticos y Computación. Universitat Politècnica Valencia (SPAIN)
}

\begin{abstract}
The introduction of the so-called Student Outcomes (SOs) in curricula is a main objective for the Universitat Politècnica de València (UPV). SOs are adaptive dimensions of students to the labour world and to lifelong learning. They are a complementary reference to academic marks, but they also grow to be academic outcomes in themselves. However, the integration of these SOs in the methodology and dynamic of traditional subjects and the obtaining of objective evidence of their achievement and results is a big challenge. UPV details in its Strategy Plan 2015-2020 the significance of these SOs, and integrates actions to promote initiatives to help meet the challenge, such as Educational Innovation and Improvement Projects (PIME). The present work explains an activity carried out within this framework.
\end{abstract}

This contribution describes an experience carried out with the collaboration of lecturers of three different subjects taught in the third year of the degree of Tourism and double degree Tourism and Business Management: Catering Production Management (CPM), New Technologies Applied to Tourism (NTAT), and Business English (BE).

The actions completed were designed to simultaneously develop and assess different SOs: Comprehension and integration $(\mathrm{CT}-01)^{1}$, Team work and leadership (CT-06), and effective communication (CT-08). Project based learning methodologies were used. Different groups of students, created using the Belbin Team Role Method, developed a catering business project. For it, they used content learnt in the subject CPM, created a website (contents based on NTAT), and presented their work in English (related BE). The contents, techniques and knowledge were developed in parallel in the three subjects and integrated in the project.

Specific assessment actions were designed for each subject, the project was considered for the final mark of all three subjects. Thus, the greatest possible amount of synergies among the subjects was created. The final result of the project was presented both in written form and in oral form in English. The three lecturers jointly evaluated the works presented, considering knowledge, content and outcomes accomplished. Two surveys were used to measure the project; one half-way, to assess its development, and another at the end, to assess the results. Then, there was a comparison of individual results vs group results. Student feedback about the adequacy of the methodology, class dynamism and learning outcomes was satisfactory, as was collaboration between lecturers.

As the main limiting factor of the project, we can mention the small size of the group, which did not allow a parallel investigation with experimental and control groups, and the difficulty to include part-time teachers of other subjects to the project due to their lack of availability, as well as the existing syllabus and class distribution, which do not allow much flexibility outside the usual activities.

Keywords: Innovation, technology, research projects, student outcomes.

\section{INTRODUCTION}

The processes aimed at obtaining better learning results are, or rather should be a constant in Higher Education (hereafter, HE). One of the strategic challenges proposed in the framework of the Strategic Plan (PEUPV 2015-2020) of the Universitat Politècnica de València [1], is to incorporate the results of student outcomes to their assessment. To this end, a mandatory system of evaluation and accreditation of these outcomes by teachers was devised and is being applied.

As it is known, outcome refers to the ability of the person "to do with knowledge" by projecting understanding into observable results. In HE, outcomes are related to the key techniques necessary for

${ }^{1}$ (CT-number): notation used in UPV to refer to the student outcomes. 
the practice of a future profession. These outcomes are conceived as transversal, as they encompass a set of disciplines (degrees) of different branches of knowledge. However, this transversality is part of the integral formation of the student. That is completed by joining both, the degree student outcomes, the degree specific subjects, with personal and interpersonal outcomes that must be transferred in the workplace, such as effective communication, time management, problem solving, and development of critical thinking or teamwork, among others. In addition to this, another issue arises from the imminent need to incorporate also citizenship outcomes, and even universal rights such as the forthcoming integration of the Sustainable Development Goals (Agenda 2030) [2] in the University curricula.

In the third follow-up report of the PEUPV (2018) [3] it was verified that practically all undergraduate and master's degrees have incorporated the transversal outcomes defined by the UPV. Nevertheless, the need to improve the system of evaluation and accreditation of these outcomes is also noted. Indeed, this is one of the aims that were proposed through the Educational Innovation and Improvement Projects (henceforth, PIME) convened annually by the UPV. The project we present was granted in the PIME call for the 2016-2017 academic year; although it is the result of a progressive methodological development grounded in the 2014-2015 and 2015-2016 PIME calls. Its main purpose is to apply a methodology for (a) the formation of heterogeneous and multidisciplinary teams in which students have to work with "non-habitual" colleagues, which forces them to develop skills working outside their comfort area; (b) the integration of project management methodologies in the learning activities in order to include the supervision of the teachers in coordination and direction tasks to improve the functioning of the teams; and (c) the adoption of general coordination objectives and networking of the subjects to adequately and jointly evaluating the SO number 6 , "teamwork and leadership".

The project is designed for the Degree in Tourism (GT) and Double-Degree in Tourism - Business Administration and Management (DGT-ADE) that are taught at the UPV in its Gandia Campus. The teachers involved in the Project were responsible for $2 \mathrm{n}$ semester subjects of the third course: Catering Production Management (CPM), New Technologies Applied to Tourism, (NTAT) and Business English (BE). Occasional collaboration of teachers of previous courses and semesters as well as other subjects that are taught simultaneously to facilitate the organization of activities and the distribution of questionnaires.

In accordance with the definitions and recommendations of the Institute of Education Sciences of the Universitat Politècnica de Catalunya [4], teamwork represents the maximum skill level for Autonomous Group Work, Guided Group Work and work done in Non-Collaborative Groups. These groups are formed to complete projects of a certain complexity, integrated by heterogeneous people, which establish personal relationships, share responsibilities, collaborate, resolve conflicts, negotiate and coordinate work.

In a first PIME project (call 2014-15), an artificial intelligence tool designed by researchers from the Group of Computer Technology-Artificial Intelligence of the UPV [5] was used to create the teams. These researchers developed an algorithm based on the popular Belbin taxonomy [6] to propose the work teams. Belbin showed that eight behavior patterns facilitate the progress of the entire team: Plant/Creative; Resource Investigator; Coordinator; Shaper; Monitor evaluator; Team worker; Implementer, and Completer-finisher. Ideally, these profiles should be balanced in a team. Conversely, if the profiles are repeated in the same group, unsatisfactory results are likely to be obtained.

In the 2015-2016 PIME call, the project is expanded in order to continue using the team training methodology, but also include new subjects in the process, and adapt it to allow various grouping criteria. The objective of evaluating the working process of the work team is also incorporated.

To carry out coordination and monitoring tasks, the project management methodology (EduScrum) [7] [8] [9], as well as the recommendations of the Project Management Institute (PMI) [10], are used.

"Scrum is a detailed method for people to work together in an enjoyable way. It also leads to great results. Scrum was developed for the IT world, it is the answer to see uncontrollable and complex IT projects. In IT, Scrum is booming: more and more huge companies have started to work with Scrum. Different areas are also turning to work with Scrum. Everywhere the benefits are tremendous: speed, work pleasure and results increase immediately. eduScrum uses the powerful ceremonies, roles and tools of Scrum. In this way the group owned scrum board gives the students an overview and the structure to make the group's work transparent. Every lesson starts with the stand-up which sees to that there is a focus and a bond, this also put them in the right work mode. The retrospective help students to continuously improve their tactics. It is a framework for a co-creative process and supporting" [11]. 
Finally, in the 2016-17call, in addition to the previous objectives, the third one is added. This way, greater and better collaboration among the teachers responsible for the development of the project is achieved. The final aim is to shape a methodological model of transversal teaching for the degrees that could be replicated in successive years. The purpose of the project was to contrast the feasibility of the tool for team building and the progressive development of SO assessment methods (6) "teamwork and leadership" to which the SO control points were subsequently added: SO-01 understanding and integration and SO-08 effective communication.

In this paper, the results obtained after the first application of the methodological model are analysed. We have investigated the students 'perception of the induced method and the group's performance by contrasting them with the teachers' perception of the transversal collaboration and the results.

\section{METHODOLOGY}

Initially, the project is based on the cooperation of five undergraduate subjects with two different objectives, on the one hand, to facilitate the creation of working groups of students common to the subjects and, on the other, to estimate what contents of the subject curricula could be shared, in order to design a learning agenda and facilitating its evaluation.

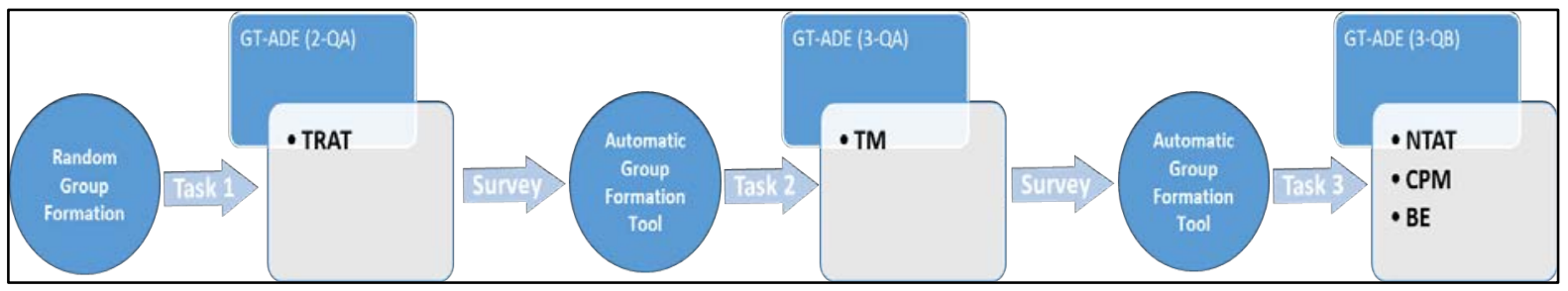

Figure 1. Levels of application of the methodology.

The pedagogical collaboration between subjects (Fig.1) has progressively developed from previous courses with different levels of involvement. The Belbin methodology was used with students of the second course while they studied Territorial Resources Applied to Tourism, (TRAT). Some tasks were assigned to them to detect and identify profiles [6]. When they were in the 3rd. year, the course was revised and refined and new teams were created, for team working in the subject Travel Management (TM). For this, two personality tests, one of self-knowledge and another of cross-evaluation on the group's partners, were designed. They allowed gathering information about possible new profiles to form the teams. The surveys were provided through the intranet institutional platform that allows exporting and importing questionnaires between subjects.

The teams were formed so as their components corresponded to all or most of the profiles explained in this theory and according to the results thrown by the computer application. Most students demonstrated to have a predominant profile, discernable in at least two activities, but not exclusively. In the second four-month period of the third year, five subjects were incorporated into the project. However, it was not possible to complete the cooperation of these five subjects due to problems in the curricular academic organisation. The main limitation in this point was in the different study curricula of the students. On the one hand, it was difficult to obtain a common population of subjects which could allow the continuation of the previously created teams, on the other, some students pursue the GT programme, whereas other are double degree students, which study some subjects in a different order than the rest. Also, not all second-year students who were given the personality tests were enrolled in the same subjects.

On top of that, there were students who attend the courses within an Erasmus programme, or students who do not have the same block of subjects per course, to which different grouping criteria must be applied. Finally, for practical convenience, effective collaboration was agreed in three subjects of very different content: NTAT, CPM, BE, playing the other two a secondary role, but relevant to support and reinforce specific content in their classes.

To facilitate transversality, of project-based learning was conveniently adapted. This pedagogical tool is based on the integration of theory and practice through the search for solutions to problems that arise in the development of work [12]. Thus, the groups of students of the same academic year worked together during the semester receiving instructions and feedback from their tutors in the indicated subjects. Timmerman and Morris [13], after extensive research on the literature on team learning for the business disciplines, defined four main categories: existing cases, news items, custom episodes and 
simulations. In our project, students worked in a creative simulation environment: they had to develop a Business Plan for the design a restoration business model of their own. The stages and times of the process (deliveries deadlines) were given aforehand, and therefore the teams had to solve the problems they faced within that timeframe. In addition to the monitoring in the classroom of the evolution of the tasks by the team there was a virtual follow-up through the EduScrum system.

Previously, after the curricular examination of each subject, the way the project could be integrated in the subject curriculum, its evaluation method and weighting in the final grade of each subject were determined. Table (1) illustrates this point.

Table 1. Integration of the Project in the subjects and weighting in the evaluation.

\begin{tabular}{|c|c|c|c|}
\hline & CPM & NTAT & BE \\
\hline & $\begin{array}{l}\text { - Classroom Observation } \\
\text { Work }(20 \%)\end{array}$ & $\begin{array}{l}\text { - Classroom Observation } \\
\text { Work }(15 \%)\end{array}$ & $\begin{array}{l}\text { - Objective Test } \\
\text { and Open answers (50\%) }\end{array}$ \\
\hline & $\begin{array}{l}\text { Project Memory } \mathbf{( 5 0 \% )} \text {. } \\
\text { Integrating multi-task } \\
\text { content (GF); (OGEII) }\end{array}$ & $\begin{array}{l}\text { - Individual Project (35\%) } \\
\text { Team Work Project } \\
(25 \%) \\
\text { Design of the Project-Web (CPM) }\end{array}$ & - Subject Project (30\%) \\
\hline & $\begin{array}{l}\text { Oral } \\
\text { communication(30\%). } \\
\text { Project explanation } \\
\text { multidisciplinary } \\
\text { (BE); (NTAT, CPM.) }\end{array}$ & $\begin{array}{l}\text { - Academy tasks } \\
(25 \%)\end{array}$ & $\begin{array}{l}\checkmark \text { Oral Communication } \\
(20 \%) \\
\text { Presentation in English } \\
\text { Website CPM-NTAT }\end{array}$ \\
\hline
\end{tabular}

To meet the objective of developing and evaluating both the specific technical knowledge of the subjects, and a series of skills and abilities that are transversal to all the degrees, the professors established a joint control system in two facets. On the one hand, the deliverables of each subject, with a specific weighting and, on the other hand, two surveys. The surveys were designed to evaluate two stages in the process: one intermediate for progress and another for final assessment of the group profile. In addition to the deliverables of development, there was a final test in which students, by teams, had to present the Business Plan to the professors. The presentation had to be carried out by explaining a website they had created in the subject of (NTAT) in English (BE). During this joint event, student outcomes were evaluated. For this, teachers used a rubric in which they individually included the personal assessment of each student in each of the SO and a final mark was agreed upon, after weighing the specialization of each teacher in each of the items.

\section{RESULTS}

After the first evaluation actions had been completed, the students were provided with a progress survey to assess their perception of the working team. The form consisted of a total of 13 issues divided into two parts. In the first part we wanted to capture what was, from the start, the positioning adopted by each student regarding the method chosen for the formation of teams. The rest of the questions referred to their perception of the functioning of the specific team they had to work in. Students were encouraged to complete the questionnaire, noting that it was not mandatory and would not be considered in any way for qualification purposes. It was provided via an intranet teaching platform in the context of the subjectbasis of the project and $74 \%$ of the students integrated in the teams answered it. At the end of the project, and before receiving the final marks, students answered a second survey aimed at capturing the general assessment regarding teamwork. 


\subsection{Results in perception}

In general terms, students say they prefer to choose or be chosen among them to form their own teams, rather than having teachers do this. However, when they were explained told that the integration of the teams responded to scientific criteria, opinion was practically polarized between those in favour and those against, followed by sceptics/indifferent at a short distance. The reason they argue $(72 \%$ of the answers) for preferring to organize their own teams is because "so I can choose people with good results"; a response that, in some way, points to a certain inclination to leadership of those who answered, so in the sense that they feel they can "choose" their peers.

The group integration methodology according to the Belbin profiles seems to work since $86 \%$ are satisfied with the work team in which they have been included. In relation to the perception of the results, more than half of the students consider that there was not much difference with the marks to which they are accustomed, although there was a $33 \%$ who perceived that their academic performance within the group has been something or much higher than usual. Regarding the homogeneity and quality of effort within the team, only 3 people, from different teams, expressed their dissatisfaction with the contributions of the rest of the team, presumably in comparison with their own, which could show the feeling of exercising a certain "dragging" effect of the rest of the group. The correlation regarding the questions about coordination, communication and responsibility among the team members was similar and consistent, given that $69 \%$ considered that the distribution of tasks or deliveries within the group has been good or very good; although (17\%) found it acceptable. Accessibility and speed of response or the effective realization of the work has been considered in the same distribution, with slight variations between the groups of percentages. Regarding the question about the fraction in which each student considered their personal contribution to the group and in what feature (question 2.8 of the questionnaire), as is usually the case in the self-supplied questionnaires, only 15 people distributed the different items in specific percentages, up to $100 \%$; the rest tended to express for each item, on a scale of $100 \%$, what the personal perception of their contribution was. In any case, relating both units of measure with the specific groups and individuals, allows a vision, which might not be absolutely real, but it will probably be at least evaluative of how each person is considered within their group, and also in relation to the responses of the other members. Finally, in the questionnaire, a final question of consistency control of the answers raised. This question was related to the first and the answers show that after the logical process of reflection that takes to complete the questionnaire, experience satisfaction within the work group falls 6 percentage points with respect to the answer, perhaps more impulsive. However, $80 \%$ of students considered the experience within the group and the intermediate period as positive or totally positive.

In the second, closing survey, students were asked to rate from 1 to 4 , where 1 is "the team has malfunctioned" and 4 "the performance has been excellent", its final assessment once the project was completed (fig.2). The average of the students stood at a positive 3.2.

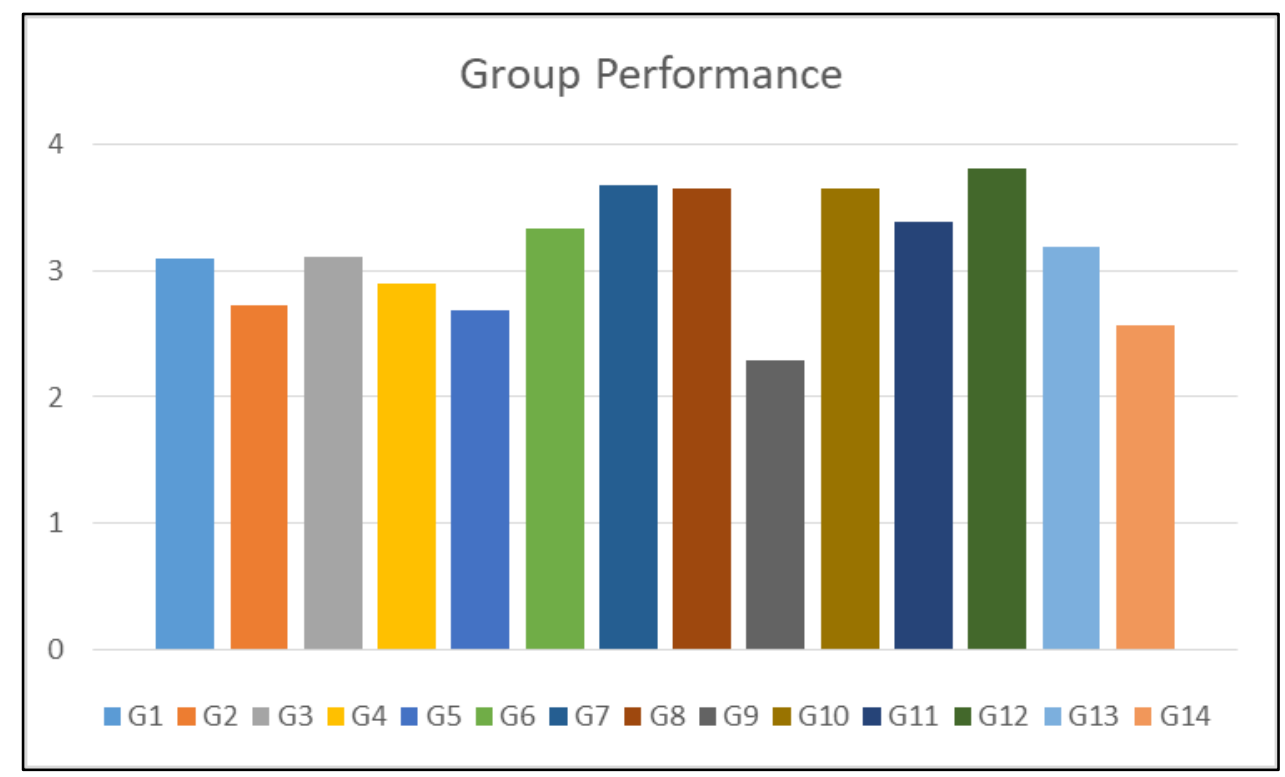

Figure 2. Final evaluation of the group of students on the functioning of their work team. 


\subsection{Performance Results}

Regarding the impact on actual results (grades of each student), it was possible to have a reference comparing the grades obtained by the same students in the call analysed with respect to a subject taught in the previous quarter. The previous subject was of the same curricular subject: Hotel Management (HM) and was taught by one of the same teachers. In the previous four-month period, teams were also created, but this time their components were chosen by the students themselves, combining team work with personal work. The results of the comparison show a personal improvement in $94 \%$ of the students in a range that ranges between $10 \%$ and $70 \%$, with the mean improvement of the students of $30 \%$, with a variance of $3.7 \%$ and a standard deviation of $19.4 \%$ (Fig.3).

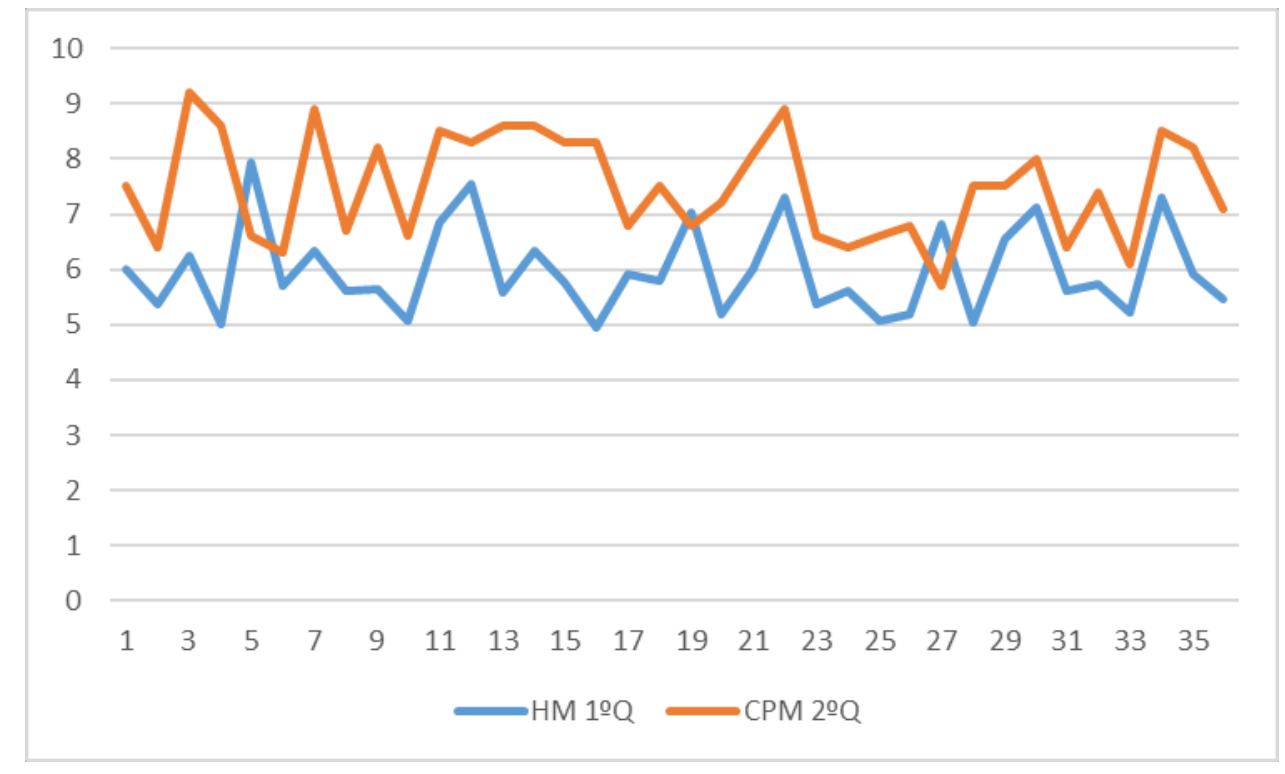

Figure 3. Difference in performance

\section{CONCLUSIONS}

In recent years, especially since the adoption of the European standards agreed in Bologna for the construction of a European Higher Education Area (EHEA), the acquisition by students of general, specific and generic or transversal outcomes has become the end natural towards which the university education tends. Progressively and to the extent that the new methodology has been implemented in all grades, courses and by the vast majority of teachers, students have been assuming the need to become more involved in their own training, acquiring greater responsibility in the maintenance of a continuous and coordinated work with their reference groups, when they have tried to work in a team context. For the development of this goal, teachers have also had to deepen the conceptual knowledge of skills and outcomes and the understanding of new teaching methodologies. To this end, institutional support has been provided through various planning, advisory and integration promotion instruments.

One of the key skills of immediate transfer to the professional field is teamwork. Ideally, in the workplace, work teams should be formed by the most capable people that the organization can recruit. A company or organization that has adequate intellectual capital will tend to form efficient teams that guarantee, at least, a satisfactory result. Knowing how to form a team for the development of a project or knowing how to adapt to teams already created or newly created, implies not only the professional assumption of the challenge, but also overcoming all kinds of emotional barriers. Therefore, it can be said that this competence is not taught, according to the traditional meaning of the term, but that it is acquired through practice in the classroom and in other social contexts.

Teachers must also adapt to these new, more collaborative, work methodologies, in which our role is that of planners, directors, counsellors and evaluators of the educational advance in many facets not yet explicitly worked. Therefore, adopting cross-disciplinary skills and outcomes as our own and reflecting them in our daily work is part of the positive reinforcement that the student receives about the evolution and effort of the whole system and not only of his own effort. In this project, one of the greatest challenges was the articulation of the collaboration between professors of different subjects and, 
therefore, departments of the UPV, in order to innovate in the development of learning with the available resources and within the limits set by the organization of the space and curricular time.

\subsection{Perception of Teachers}

The academic results achieved by the students are satisfactory. The operation of the teams was better when they reached a certain degree of experience. Students were able to perceive the benefits of working with combined subjects. However, the creation of these heterogeneous teams, displacing students from their comfort zone, is not always well understood. Teams are made up of people and individual behaviour is not constant over time. Personal circumstances influence performance.

Therefore, although in the past, a given team managed to develop a good job, it is important to keep track of the work teams already trained. This control is possible through technological tools that allow to visualize the progress or stagnation of the work. But attention must also be paid to what the members' perception of the internal performance of the group is.

The correct communication to the students by all the professors involved, of what it is and for what reason a certain methodology of work is applied, as well as what results are expected to be achieved, is fundamental for the success of the project. Students must perceive from the beginning that it is a coherent and unified project. The decision on what should be the common thread that links the subjects is essential. In our case, it was the intervention on the development of a business project of one of the subjects on which three transversal competences could be developed and measured as a control point. Formalizing this agreement between subjects helps to commit to the project and to choose the combination of subjects that have greater compatibility. It also shows that reaching a proven teaching model that can be replicated over time requires several years of testing.

\subsection{Perception of the students}

In addition to the results obtained in the surveys and reflected in previous points, the students, spontaneously, either through email, or as conclusions of the work they developed gave us some comments that we transcribe literally:

- "Estamos contentos con el trabajo realizado, ya que hemos aprendido muchísimo, no sólo con lo relacionado con esta asignatura (CPM) sino también con nuevas tecnologías (NTAT). El haber aprendido a crear una página web y más concretamente de un negocio que tú misma/o has diseñado, es enorgullecedor y gratificante." (Grupo1; 3 integrantes; Grado en Turismo)

- "Y, por último, añadir que se ha disfrutado muchísimo con este proyecto, ya que has tenido que indagar todas las leyes para poder crear un establecimiento, has comparado gastos e ingresos, has estimado cantidades... etc. has trasladado la visión que quizás leyéndote apuntes de clase no la obtienes, a la vida real. En conclusión, has conseguido un proyecto que podría llevarse a cabo en un futuro" (Grupo 14; 3 integrantes; DG-TADE)

- "Tras realizar todas y cada una de las prácticas, hemos sacado la conclusión que hemos tenido la oportunidad de poder aprender sobre restauración, $\mathrm{RRHH}$ y finanzas entre otros aspectos. De esta manera nos sentimos muy realizados, ya que con un solo trabajo hemos adquirido distintas aptitudes que creemos que nos vendrán muy bien para el futuro. A pesar de que no ha sido una elaboración sencilla por tener dificultades en el momento de realizar los cálculos y entendimiento de alguna parte del temario. Sin embargo, a pesar de las adversidades, el equipo lo ha sacado adelante y está orgulloso del proyecto que ha llevado a cabo." (Grupo3; 4 integrantes; GT)

- "Con la realización de este trabajo hemos aplicado los contenidos teóricos de las cinco asignaturas a través de la elaboración, diseño y desarrollo de una idea de negocio Restaurante Es un proyecto complejo en el que hemos trabajado en equipo para sacar adelante este concepto en el que hemos desarrollado y mejorado nuestras habilidades técnicas y transversales, ya que hemos puesto en práctica la teoría desde los aspectos más básicos hasta los más complejos. Para ello hemos tenido que ser creativas e innovadoras para sacar adelante este proyecto transversal en el que hemos tenido que presentar un plan de viabilidad de un modelo de empresa de restauración. En definitiva, este proyecto o trabajo resume todos los conocimientos teóricos de las asignaturas aplicados de una manera práctica gracias a los cuales hemos mejorado nuestras destrezas en el sector de la restauración, tecnológico, financiero, internacional y con los recursos humanos" (Grupo 6; 3 integrantes; GT) 
- "Realizar este proyecto nos ha resultado muy interesante puesto que hemos aprendido a seguir un plan de negocio y hemos aplicado conceptos como la innovación y la creatividad. El proyecto nos ha ayudado a conocer nuestros puntos fuertes y débiles ya que nos ha supuesto mucho esfuerzo realizar las últimas partes del proyecto relacionadas con los costes y la financiación y, sin embargo, las partes más creativas como la creación de la oferta gastronómica o la definición de la misión, visión y valores han resultado menos complicadas y más divertidas de realizar".

From the point of view of the research, it is important to highlight some limitations to the work. The exclusive application to EPSG undergraduate students in the indicated degrees implies that the group size does not allow to experiment with two groups simultaneously. The comparison of marks has been made with respect to two subjects that present similarity of variables: similar subject, identical students and identical teacher and same academic year, but it is not transferable to the rest of the subjects that have intervened in the project. In the short term, another limitation is the complexity in the creation of teams according to the Belbin profiles, given that the computer application is not institutionalized and, therefore, depends on the availability of its creators. A final limitation is the impossibility to integrate more subjects in the project, due to the different learning curricula of students. Two of the subjects initially planned are taught in the third year for the GT students, but they are learnt by second year DGTADE students, so that they cannot be in the same working groups as the rest.

\section{ACKNOWLEDGEMENTS}

This work is supported by the projects PIME B-05/2017 \& PIME B-22/2016 from UPV.

\section{REFERENCES}

[1] Universitat Politécnica de València, “Plan Estratégico UPV 2015-2020," Valencia , 2015.

[2] Universitat Politécnica de Valéncia, "Plan Estratégico UPV 2015-2020. Tercer Informe de Seguimiento," UPV, Valencia , 2018.

[3] R. Belbin, Team Roles at Work, London : Routledge, 2010.

[4] United Nations, General Assembly, "Transforming our world: the 2030 Agenda for Sustainable Development," 2015.

[5] A. Delhij, R. van Soligen y W. Wijnands, «EduScrum. Versión 1.2,» 2015, Septiembre.

[6] A. Jurado-Navas and R. Muñoz-Luna, "Scrum Methodology in Higher Education: Innovation in teaching, Learning and Assessment," International Journal of Higher Education, vol. 6, no. 6, pp. 1-18, 7 November 2017.

[7] E. Zouganeli, V. Tysso, B. Feng, K. Arnesen and N. Kapetanovic, "Project-based learning in programming classes- the effect of open project scope on student motivation and learning outcome," in Proceeding of the 19th World Congress. The International Federation of Automatic Control, Cape Town, South Africa. August 24-29, 2014 , 2014.

[8] V. Van den Bergh, D. Mortelmans, P. Spooren, P. Van Petegem, D. Gijbels and G. Vanthournout, "New Assessment modes within project-based education-The Stakeholders," Studies in Educational Evaluation, no. 32, pp. 345-368, 2006.

[9] B. Woodward, P. Sendall and W. Ceccucci, "Integrating Soft Skill Competencies Through Project-based Learning Across the Information Systems Curriculum," Information Systems Education Journal, vol. 8, no. 8, pp. 1-16, 2 March 2010.

[10] B. Restrepo Gómez, "Theoretical foundations of competency-based assessment: historical traceability of the concept," Uni-pluri/versidad, vol. 13, no. 2, pp. 14-23, 2552013.

[11] Institut de Ciències de I'Educació, "Treball en Equip," 411 2008. [Online]. Available: https://www.upc.edu/ice/ca/innovacio-docent/publicacions_ice/quaderns-per-treballar-lescompetencies-generiques-a-les-assignatures/183.pdf. [Accessed 2 enero 2018]. 
[12] J. Timmerman and R. Morris, "Creation of Exercises for Team-Based Learning in Business," International Journal of Teaching adn Learing in Higher Education, vol. 27, no. 2, pp. 280-291, 2015.

[13] Project Managemente Institute, A Guide to the Project Mangement Body of Knowledge (PMBOK@Guide)- Fifth Edition, 2017.

[14] eduScrum, 2018. [Online]. Available: http://eduscrum.nl/en/about-eduscrum.

[15] J. Alberola, E. Val, V. Sánchez, A. Palomares and M. Teruel, "Artificial intelligence tool for team formation in the classrom," Knowleg-Based Systems, no. 101, pp. 1-14, 2016. 